\title{
Development of an optical swirl sensor for DI-diesel engines
}

\begin{abstract}
In this paper the systematic development of an optical swirl sensor to measure the swirl ratio in an operating serial turbocharged DI-diesel engine is described. The optical sensor detects the visible light of the combustion, in particular the emission of the sooting flame in a wavelength range from $600 \mathrm{~nm}$ up to $1000 \mathrm{~nm}$. The acceptance angle is so small that the soot clouds from every spray can be detected as they are being turned under the optical sensor by the swirling flow. In a first part the new optical probe method was validated on a transparent engine by comparison with high speed video recordings. In the second part several hardware variations were made on a serial DI-diesel engine which was equipped with a variable swirl valve. The influence of the opened-and closed swirl valve constellation and the piston geometry on the swirl ratio was measured with the optical probe technique. The results were compared with a zero dimensional simulation model. There was a good agreement between the swirl measurements and the 0D-model. The optical swirl sensor has proven to be a powerful tool to optimise the combustion process. Without any modifications on the cylinder head, the effect of application parameters and hardware parts on the swirl strength can be quantified for all engine loads and speeds.
\end{abstract}

Key words: swirl flow, direct-injection diesel engine, optical measurement techniques

\section{Rozwój optycznego czujnika zawirowania do silników o ZS z wtryskiem bezpośrednim}

\begin{abstract}
W artykule opisano rozwój optycznego czujnika zawirowania, który jest wykorzystywany do pomiarów stopnia zawirowania w pracującym silniku o ZS z wtryskiem bezpośrednim i turbodoładowaniem. Czujnik optyczny rejestruje widzialne światło spalania, w szczególności promieniowanie sadzy w płomieniu dyfuzyjnym w zakresie dlugości fal od 600 do $1000 \mathrm{~nm}$. Kąt obserwacji czujnika optycznego jest wystarczająco mały do wykrycia ruchu obłoku promieniujacej sadzy wywołanego przez zawirowanie ładunku w cylindrze, dla każdej strugi wtryskiwanego paliwa. W początkowej części artykutu nowa metoda badań czujnikiem optycznym została zweryfikowana na silniku transparentnym przez porównanie z wynikami obserwacji ruchu płomienia zarejestrowanymi za pomoca szybkiego filmowania. W dalszej części artykułu przedstawiono kilka zmian konstrukcyjnych wykonanych na seryjnym silniku o ZS typu DI, który zostat wyposażony w zawór wytwarzajacy zmienne zawirowanie obwodowe. Wpływ otwierania i zamykania tego zaworu oraz geometrii korony tłoka na stopień zawirowania tadunku określono przy wykorzystaniu techniki pomiarów optycznych. Otrzymane wyniki porównano z wynikami symulacji uzyskanymi dla modelu 0-wymiarowego. Stwierdzono zgodność wyników pomiarów zawirowania i symulacji modelu OD. Optyczny czujnik zawirowania okazat się przydatnym narzędziem do optymalizowania procesu spalania. Wplyw parametrów regulacyjnych oraz elementów konstrukcyjnych na stopień zawirowania może być wyznaczony dla całego zakresu obciażenia i prędkości obrotowej silnika bez jakichkolwiek modyfikacji konstrukcyjnych głowicy silnika.
\end{abstract}

Słowa kluczowe: przeplyw wirowy, silnik z wtryskiem bezpośrednim, techniki pomiarów optycznych

\section{Introduction}

The amount of soot at a certain $\mathrm{NO}_{\mathrm{x}}$-level formed during the combustion process in DI-diesel engines is governed by the interaction of the swirling flow with the high pressure fuel injection. The optimal swirl level in every load point is required to fulfil present and future legislative requirements.

The engine is equipped with a variable swirl valve, which allows varying the swirl intensity. When the swirl valve is closed, only the tangential intake port is throughflown and a very high swirling flow is induced. The swirl valve can be opened continuously. When both intake ports are open, only a low swirl is generated. In Fig. 1 the EGRtrades for the load point at $1500 \mathrm{rpm}$ and a mean effective pressure of 3 bar, which is characteristic for the first phase in the European driving cycle, for different swirl valve posi-

\section{Wstęp}

Ilość sadzy przy pewnym poziomie emisji $\mathrm{NO}_{\mathrm{x}}$ powstającej podczas procesu spalania wynika z interakcji pomiędzy przepływem wirowym czynnika a wysokociśnieniowym wtryskiem paliwa. Do zapewnienia obecnych i przyszłych wymagań normatywnych niezbędne jest zapewnienie optymalnego zawirowania ładunku w każdym punkcie pracy silnika.

Silnik wyposażono w zawór do regulacji zawirowania, który umożliwia różnicowanie jego intensywności. Kiedy zawór zawirowujący jest zamknięty, przepływ następuje tylko przez styczny kanał dolotowy i tworzy się silne zawirowanie obwodowe. Zawór zawirowujący może pozostawać stale otwarty. Gdy oba zawory dolotowe są otwarte, wytwarzane jest tylko słabe zawirowanie.

Na rysunku 1 można zaobserwować przebiegi recyrkulacji spalin (EGR) dla różnego położenia zaworu zawiro- 
tions are shown. In the $\mathrm{NO}_{\mathrm{x}}$-soot trade of Fig. 1, the immense influence of the swirl valve position can be seen. The soot emissions can be reduced from 1.1 to 0.18 at a $\mathrm{NO}_{\mathrm{x}}-$ level of $50 \mathrm{ppm}$ by closing the swirl valve. The hydrocarbon and carbon monoxide emissions increase by closing the swirl valve. The specific fuel consumption shows little reaction by closing the swirl valve, only at the completely 2 closed swirl valve position there is a very large increase of the specific fuel consumption. When the swirl valve is closed from the $60^{\circ}$ to the $90^{\circ}$-position and the swirl number after Tippelmann [1] is increased from 0.6 to 0.9 , the soot emissions can be reduced from 0.5 to 0.18 . The disadvantage of the higher swirl intensity can be seen in Fig. 2. The specific fuel consumption is increased by an almost $15 \mathrm{~g} / \mathrm{kW} \cdot \mathrm{h}$. Such deterioration usually leads to a fuel increase of 0.11 up to 0.31 in the European driving cycle.

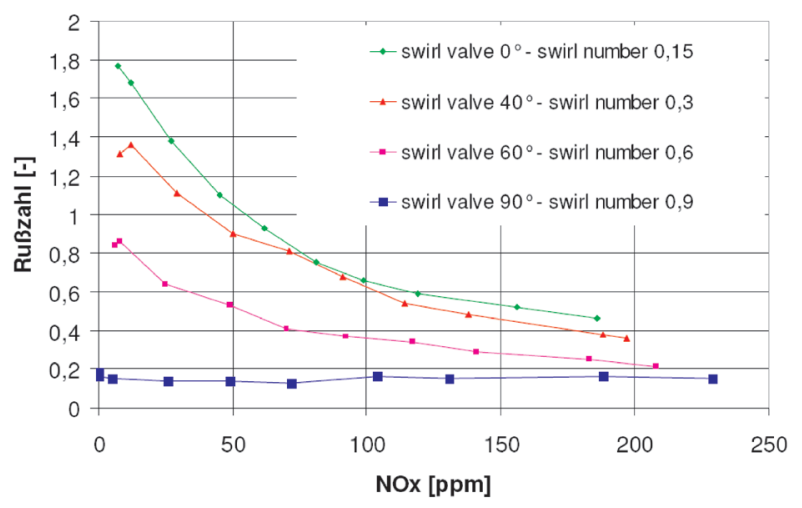

Fig. 1. Effect of a swirl and EGR variation at $1500 \mathrm{rpm}$ and $\mathrm{p}_{\mathrm{me}}=3 \mathrm{bar}$ on the $\mathrm{NO}_{\mathrm{x}}$ and soot emissions

Rys. 1. Wplyw zawirowania i zmiany stopnia recyrkulacji spalin (EGR) na emisję NO i sadzy przy prędkości obrotowej 1500 obr/min i średnim ciśnieniu użytecznym $p_{m e}=3$ bary

These measurements show the conflict between the reduction of the exhaust gas emissions and fuel consumption. For future diesel engines a better compromise between the $\mathrm{NO}_{\mathrm{x}}$ emissions and the fuel consumption is necessary since the $\mathrm{CO}_{2}$ emissions will also be limited to $130 \mathrm{~g} / \mathrm{km}$ in the year 2014 [2]. Therefore, new measurement methods which allow detailed insights in the governing processes are needed. A contribution to this demand is the development of the so called "optical swirl sensor".

\section{Definition and mathematical modelling of the swirl ratio}

\subsection{General remarks}

Swirl measurements have become an established process in the development of diesel engines. Usually, the swirl flow induced from the intake ports of a cylinder head is determined. The charge motion in the cylinder is very complex. Simplified it can be described by the swirl or tumble number. The model presented in this article computes the swirl development during the induction stroke. It also calculates the swirl modification during the compression stroke. The model considers the influence of the camshaft (valve wującego przy obciążeniu częściowym silnika, prędkości obrotowej 1500 obr/min i średnim ciśnieniu użytecznym 3 bary, które jest charakterystyczne dla pierwszej fazy Jezdnego Cyklu Europejskiego.

Na krzywej zależności NO -sadza (rys. 1) można zaobserwować ogromny wpływ położenia zaworu zawirowującego. Emisja sadzy może być zredukowana przez zawór zawirowania, który pozwala na zmianę zawirowania od 1,1 do 0,18 dla $\mathrm{NO}_{\mathrm{x}}$ na poziomie $50 \mathrm{ppm}$ przez domknięcie zaworu. Emisja węglowodorów i tlenku węgla wzrasta wraz z domykaniem zaworu zawirowującego. Przebieg jednostkowego zużycia paliwa wykazuje tylko nieznaczną wrażliwość na domykanie zaworu zawirowującego, a tylko przy jego całkowitym zamknięciu występuje bardzo duży wzrost jednostkowego zużycia paliwa. Kiedy zawór zawirowujący jest zamykany od pozycji $60^{\circ}$ do $90^{\circ}$, a liczba wirowa wg Tippelmanna [1] zwiększa się od 0,6 do 0,9, wtedy emisja sadzy może ulec zmniejszeniu od 0,5 do 0,18. Wada zwiększonej intensywności zawirowania jest widoczna na rys. 2. Jednostkowe zużycie paliwa wzrasta wówczas o prawie $15 \mathrm{~g} / \mathrm{kW} \cdot \mathrm{h}$. Takie pogorszenie zwykle prowadzi do zwiększenia zużycia paliwa od 0,1 aż do 0,3 w europejskim cyklu jezdnym.

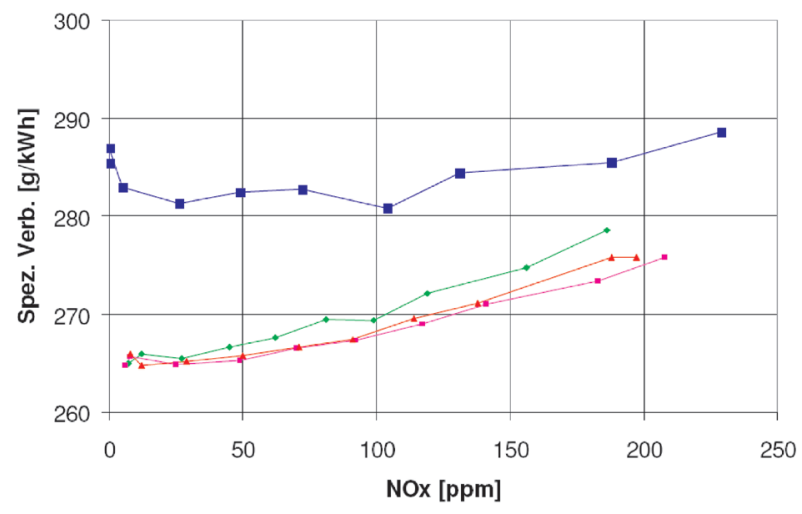

Fig. 2. Effect of a swirl and EGR variation at velocity $1500 \mathrm{rpm}$ and $\mathrm{p}_{\mathrm{me}}=3$ bar on the $\mathrm{NO}_{\mathrm{x}}$ emissions and the specific fuel consumption Rys. 2. Wplyw zawirowania i zmiany stopnia recyrkulacji spalin (EGR) na emisję $N O_{x}$ i jednostkowe zużycie paliwa przy prędkości obrotowej $1500 \mathrm{obr} / \mathrm{min}$ i średnim ciśnieniu użytecznym $p_{m e}=3$ bary

Z powyższego wynika sprzeczność między redukcją emisji związków toksycznych a zużyciem paliwa. Dla przyszłych silników o ZS konieczne jest poszukiwanie kompromisu pomiędzy emisją $\mathrm{NO}_{\mathrm{x}}$ a zużyciem paliwa, ponieważ w $2014 \mathrm{r}$. emisja dwutlenku węgla będzie ograniczona do $130 \mathrm{~g} / \mathrm{km}$. $\mathrm{Z}$ tego powodu potrzebne są nowe metody badawcze, które pozwolą na szczegółowy wgląd w zarządzanie procesem spalania. Koniecznym wkładem do zarządzania procesem jest rozwój tzw. optycznego czujnika zawirowania.

\section{Definicje i modelowanie matematyczne stopnia zawirowania}

\subsection{Uwagi ogólne}

Pomiar zawirowania obwodowego (typu swirl) w silniku o ZS stał się zasadniczym pomiarem w rozwoju silników o ZS. Przeważnie bada się zawirowanie obwodowe wywoły- 
lift timing), the crankshaft kinematics and the piston bowl geometry. This allows a comparison between measured and simulated swirl numbers.

\subsection{Swirl measurement}

Steady state test rigs are used for swirl measurement. A common technique uses a paddle wheel mounted on the cylinder axis. The measured quantity is the rotation speed of the paddle. Another possibility is to use an impulse swirl meter to determine the total torque induced in the cylinder. This technique has superseded the paddle wheel and is therefore used to give the start values for swirl computation during induction stroke [1]. In general, the swirl number is defined as [3]:

$$
\mathrm{D}=\frac{\varpi_{\text {air }}}{\varpi_{\text {engine }}}=\frac{\varpi_{\text {air }}}{2 \cdot \pi \cdot \mathrm{n}}
$$

Since the engine speed $\mathrm{n}$ is known, one has to compute the angular velocity $\varpi_{\text {air }}$. With the assumption of a solid body rotation, the angular velocity can be written as:

$$
\varpi_{\text {air }}=\frac{2 \cdot \mathrm{M}}{\dot{\mathrm{V}} \cdot \rho \cdot \mathrm{r}^{2}}=\frac{8 \cdot \mathrm{M}}{\dot{\mathrm{m}} \cdot \mathrm{d}^{2}}
$$

In general, the result of a swirl measurement is the torque which is also dependent of the valve lift. In order to model the swirl generation in the cylinder with more accuracy, the torque and the mass flow rate values have to be determined for the complete valve lift curve. To do so, equation (2) has to be changed in:

$$
\varpi_{\text {air }}=\frac{8}{\mathrm{~d}^{2}} \cdot \frac{\int_{\text {IVO }}^{\text {IVC }} \mathrm{M} \cdot \mathrm{d} \alpha}{\int_{\text {IVO }}^{\text {IVC }} \dot{\mathrm{m}} \cdot \mathrm{d} \alpha}=\frac{8}{\mathrm{~d}^{2}} \cdot \frac{\sum_{\mathrm{IVC}}^{\text {IVO }} \mathrm{M} \cdot \Delta \alpha}{\sum_{\text {IVC }}^{\text {IVO }} \dot{\mathrm{m}} \cdot \Delta \alpha}
$$

During the compression stroke it is possible to model the swirl evaluation with or without friction losses. For simplification the following derivations neglect friction. Then, the conservation law of angular momentum yields:

$$
\begin{aligned}
& \frac{\mathrm{dL}}{\mathrm{dt}}=0 \\
& \mathrm{~L}=\text { const. }
\end{aligned}
$$

The angular momentum $\mathrm{L}$ is defined as:

$$
\begin{aligned}
& \mathrm{L}=\mathrm{J}_{\text {air }} \cdot \varpi_{\text {air }}=\text { const } \\
& \mathrm{J}_{1} \cdot \varpi_{1}=\mathrm{J}_{2} \cdot \varpi_{2}
\end{aligned}
$$

Since the charge motion is modelled without friction, there is no change in angular momentum. The angular velocity increases because the moment of inertia of the rotating air is decreasing as the piston moves from bottom dead centre to top dead centre. Therefore, we have to compute, the change of inertia over the crank angle from BDC to TDC. wane przez kanały dolotowe w głowicy. Ruch ładunku w cylindrze jest bardzo złożony. Upraszczając, może on być opisany przez liczbę wirową dla zawirowania obwodowego (typu swirl) lub beczkowego (typu tumbel). Model zaprezentowany w tym artykule pozwala obliczyć powstawanie zawirowania podczas suwu dolotu. Umożliwia obliczanie zmiany zawirowania w czasie suwu sprężania. Model uwzględnia wpływ rozrządu (wzniosu zaworu dolotowego), kinematyki wałka rozrządu oraz geometrii komory spalania na zawirowanie. To pozwoliło na porównanie otrzymanych wyników z symulacji z wynikami badań empirycznych.

\subsection{Pomiar zawirowania obwodowego}

Do pomiaru zawirowania obwodowego posłużyło stacjonarne stanowisko badawcze. Powszechnie jest stosowane stanowisko $\mathrm{z}$ anemometrem skrzydełkowym montowanym w osi cylindra. Wielkością mierzoną jest prędkość obrotu skrzydełek anemometru. Innym sposobem pomiaru tego zawirowania jest użycie miernika impulsowego do określenia całkowitego momentu wirowania wytworzonego w cylindrze. Ta technika wypiera pomiar za pomocą anemometru skrzydełkowego i daje możliwość obliczenia zawirowania w suwie dolotu [1]. Ogólnie liczba wirowa jest definiowana jako (1) [3].

Gdy znana jest prędkość obrotowa silnika n, należy obliczyć prędkość kątową $\varpi_{\text {air }}$. Przyjmując założenie obrotu ciała sztywnego, prędkość kątowa $\varpi_{\text {air }}$ przyjmuje postać (2).

Ogólnie, wynikiem pomiaru zawirowania jest moment obrotowy, który zależy od wzniosu zaworu. W celu modelowania powstawania zawirowania obwodowego z większą dokładnością model obrotowy i prędkość przepływu czynnika przez zawór należy określić dla całkowitego skoku zaworu. W tym celu należy równanie (2) przekształcić do postaci (3).

W czasie suwu sprężania możliwe jest modelowanie powstawania zawirowania obwodowego ze stratami lub bez strat tarcia. W celu uproszczenia pominięto wpływ tarcia i poniższa pochodna zaniedbuje tarcie. Wówczas równanie zachowania momentu kątowego przyjmuje postać (4).

Kręt definiuje się jako równanie (5).

W czasie ruchu ładunku zamodelowanego bez tarcia nie występują zmiany krętu. Prędkość kątowa wzrasta, ponieważ moment bezwładności wirującego powietrza zmniejsza się w czasie ruchu tłoka $z$ dolnego martwego punktu (DMP) do górnego martwego punktu (GMP). Dlatego trzeba obliczyć zmiany bezwładności ładunku w funkcji obrotu wału korbowego z DMP do GMP.

Moment bezwładności wirującego powietrza, zgodnie $\mathrm{z}$ rys. 3 , wynosi (6).

Na rysunku 4 przedstawiono przebieg powstawania wiru obwodowego w czasie suwów dolotu i sprężania. Od DMP do GMP moment bezwładności zmienia się o współczynnik $\left(\mathrm{d}_{\mathrm{m}} / \mathrm{d}_{\mathrm{z}}\right)^{2}$. Dlatego prędkość kątowa $\varpi_{\text {air }}$ wzrasta o wartość współczynnika $\left(\mathrm{d}_{\mathrm{z}} / \mathrm{d}_{\mathrm{m}}\right)^{2}$. W pracującym silniku obserwowany wzrost zawirowania obwodowego jest mniejszy ze względu na tarcie na ściankach cylindra oraz w wyniku wpływu innych czynników.

W przyszłości model będzie uwzględniać tarcia na ściankach cylindra w czasie suwu sprężania. W takich warunkach równanie (4) przybierze postać (7). 
The moment of inertia of the rotating air according to the Fig. 3 becomes:

$$
J_{i}=J_{B D C} \cdot \frac{\frac{x_{i}}{h} \cdot\left(\frac{d_{m}}{d_{z}}\right)^{4}}{\frac{x_{i}}{h} \cdot\left(\frac{d_{m}}{d_{z}}\right)^{2}}
$$

Figure 4 shows the swirl evaluation during induction and compression stroke. From BDC to TDC the moment of inertia changes with the factor $\left(\mathrm{d}_{\mathrm{m}} / \mathrm{d}_{\mathrm{z}}\right)^{2}$. Therefore, the angular velocity $\varpi_{\text {air }}$ increases by the factor $\left(d_{z} / d_{m}\right)^{2}$. In an operating engine the observed increase in swirl is less due to wall friction and other factors.

In the future the model will consider wall friction during compression stroke. Under this condition equation (4) becomes:

$$
\frac{\mathrm{dL}}{\mathrm{dt}}=-\mathrm{M}_{\mathrm{r}}
$$

Looking at equation (7) the angular moment is no longer constant. The friction moment has to be calculated with respect to the time. The transformation of equation (7) leads to:

$$
\begin{aligned}
& \frac{d(J \cdot \varpi)}{d t}=-M_{r} \\
& J_{i} \cdot \varpi_{i}=-\int M_{r} \cdot d+J_{i+1} \cdot \varpi_{i+1}
\end{aligned}
$$

This equation has to be solved iterative, because the term $M_{r}$ depends on the angular velocity $\varpi$. Results of the advanced model will be presented in the future.

\section{The optical swirl measurement system}

The optical swirl measurement system is derived from the Kistler 2-color method system, which is available on the market [4]. The system is adapted to measure the swirling flow in the combustion chamber.

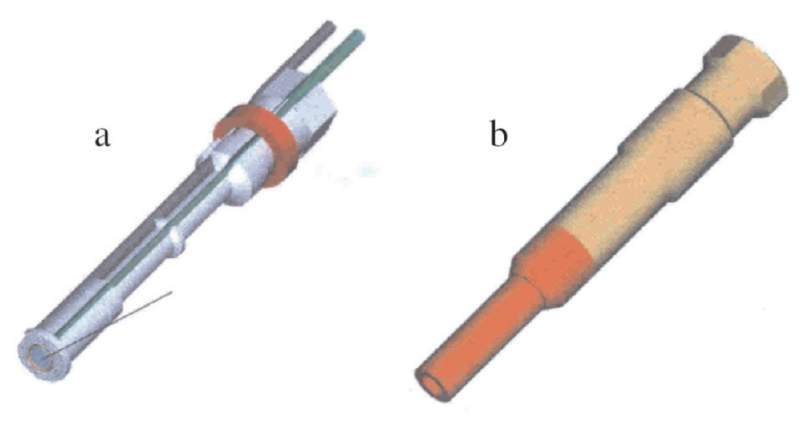

C

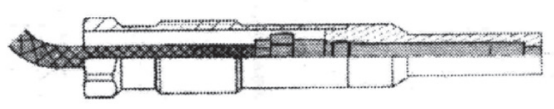

Fig. 5. The optical swirl sensor: (a) optical fibre with quartz glass window, (b) adapter, (c) the sensor mounted in the adapter

Rys. 5. Optyczny czujnik pomiaru zawirowania obwodowego: (a) światłowód z oknem kwarcowym, (b) adapter, (c) czujnik zamontowany $w$ adapterze
Z równania (7) wynika, że kręt nie jest już stały. Moment tarcia należy obliczyć w zależności od czasu. Przekształcenie równania (7) prowadzi do równania (8).

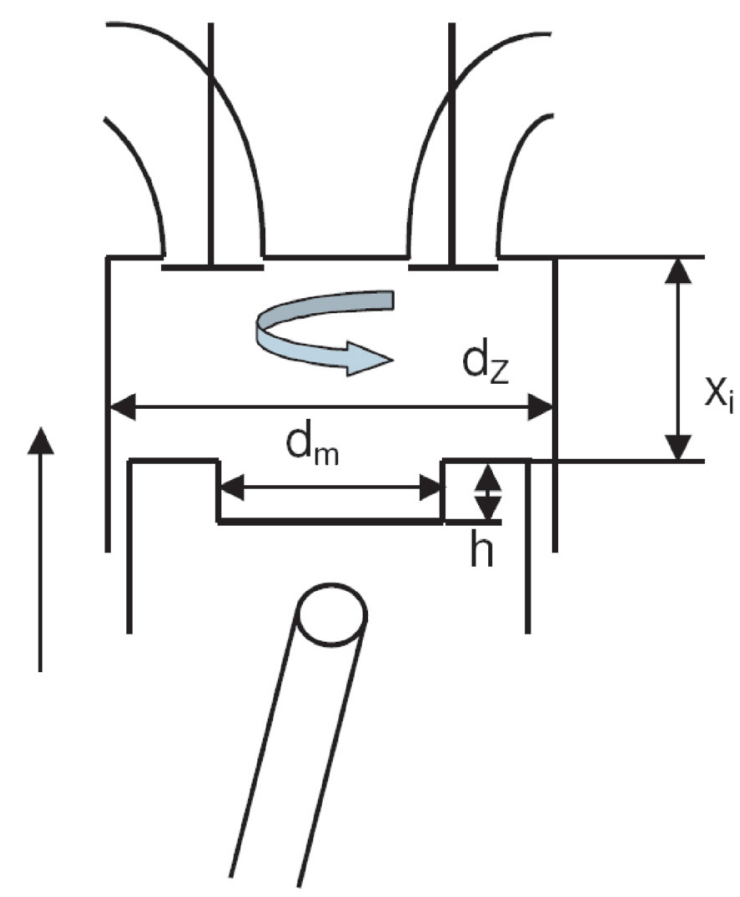

Fig. 3. Swirl modification during compression stroke Rys. 3. Zawirowanie obwodowe ładunku podczas suwu sprężania

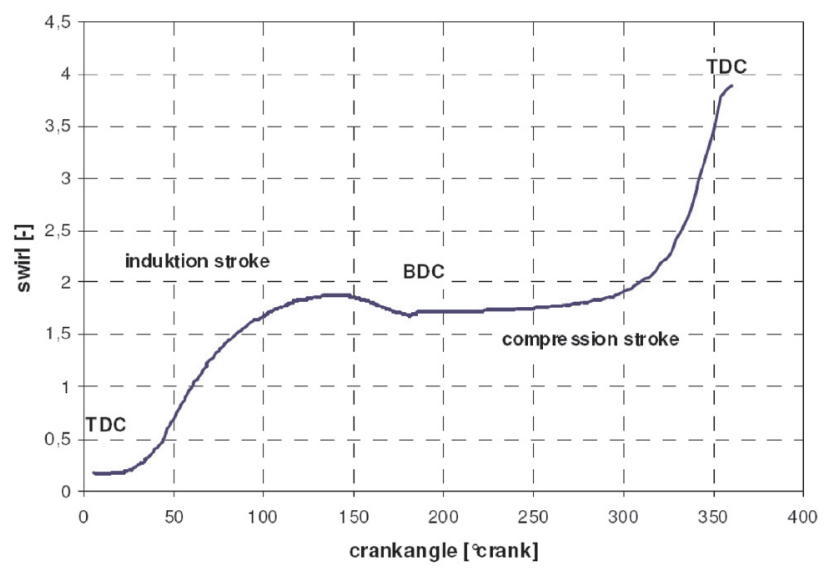

Fig. 4. Computed swirl number during induction and compression stroke Rys. 4. Obliczona wartość liczby wirowej podczas suwów dolotu i sprężania

To równanie musi być rozwiązane metodą iteracyjną, ponieważ wielkość $M_{\mathrm{r}}$ zależy od prędkości kątowej Rezultaty w ten sposób rozszerzonego modelu będą przedstawione w przyszłości.

\section{Optyczny system pomiaru zawirowania}

Optyczny system pomiaru zawirowania obwodowego został rozwinięty z systemu badań metodą dwubarwową, firmy Kistler, który jest osiągalny w handlu [4]. System ten przystosowano do pomiaru przepływu obwodowego w komorze spalania. 
The technical specifications of the components are described in [5]. The swirl sensor operates motionless and doesn't interfere with the combustion process. The miniaturised optical sensor shown in Fig. 5a is mounted in an adapter (Fig. 5b) and placed in the glow plug bore of the engine and replaces the standard glow plug. The complete measurement system is shown in Fig. 6. The measurement system consists of a front end quartz glass lens (a) and an optical fibre (b) to lead the light to an optical detector unit (c). The optical detector unit is a photo diode which transforms the emitted light intensity into an electrical current. This signal is recorded by the data acquisition system Indicom (d). The optical sensor detects the visible and near infrared light of the combustion, in particular the emission of the soothing flame in a wavelength range from $600 \mathrm{~nm}$ up to $1000 \mathrm{~nm}$.
Specyfikacja techniczna elementów systemu zastała opisana w pracy [5]. Optyczny czujnik zawirowania nie ma elementów ruchomych i nie wpływa na przebieg procesu spalania. Zminiaturyzowany czujnik zawirowania przedstawiony na rys. 5a jest zamontowany w adapterze (rys. 5b) i umieszczony w otworze świecy żarowej, zastępując w silniku standardową świecę żarową. Kompletny system pomiarowy przedstawiono na rys. 6 . System pomiarowy składa się z soczewki ze szkła kwarcowego (a) oraz światłowodu (b), który prowadzi światło do optycznego detektora światła (c). Optyczny detektor światła jest wyposażony w fotodiody, które przetwarzają emitowaną intensywność światła na prąd elektryczny. Sygnał prądowy jest zapisywany w systemie akwizycji danych Indicom (d). Czujnik optyczny wykrywa promieniowanie światła widzialne i w

b

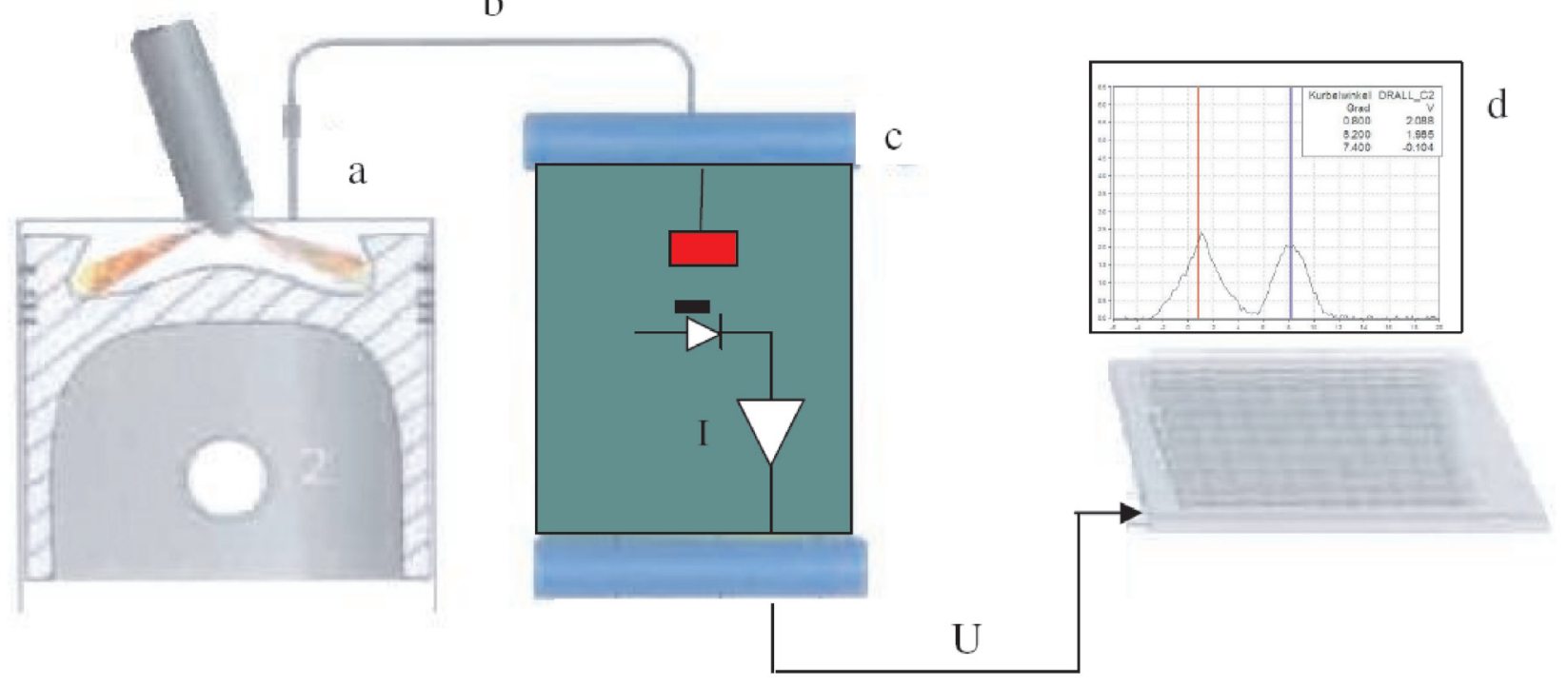

Fig. 6. The optical swirl system with: (a) swirl sensor, (b) optical fibre, (c) optical signal amplifier, (d) data acquisition system Rys. 6. Optyczny system pomiaru zawirowania obwodowego: (a) czujnik zawirowania, (b) światłowód, (c) optyczny detektor światła, (d) system akwizycji danych

The acceptance angle had to be reduced to an absolute minimum. In this way it is possible to correlate a signal intensity peak with a single soothing coil. The design of the optical glass lens in combination with a suitable adapter allowed realising an acceptance angle of about 1 degree.

The system was adapted in order to obtain the maximum light intensity of the soothing flames. Therefore, the optical filters of the standard system were removed and the broadband light emissions in the visible range were captured. The signal intensity could be increased significantly in this way.

Due to the small acceptance angle the soot clouds from every spray can be detected as they are being turned under the optical sensor by the swirling flow. At high swirl, the single-cycle signal trace shows a high first maximum during the flame development and two or three succeeding smaller relative maxima when the soot clouds from windward neighbouring sprays passes the detection cone of the sensor. zakresie bliskiej podczerwieni, szczególnie promieniowanie płomieni dyspersyjnych w silniku w zakresie długości fali od 600 do $1000 \mathrm{~nm}$.

Kąt obserwacji czujnika musiał być ograniczony do minimum. W ten sposób jest możliwe skorelowanie piku sygnału otrzymywanego z czujnika z powstałymi w komorze spalania obłokami sadzy. Konstrukcja soczewki w powiązaniu z odpowiednim adapterem pozwoliła na uzyskanie właściwego kąta obserwacji, który wynosił około $1^{\circ}$.

System został przystosowany do uzyskiwania maksymalnej intensywności światła płomienia dyspersyjnego palącej się sadzy. Dlatego optyczne filtry, które występują w standardowym systemie zostały usunięte, a rejestrowano światła widzialne w całej szerokości widma. W ten sposób można było znacząco wzmocnić intensywność sygnału.

Ze względu na mały kąt obserwacji możliwe jest wykrycie obłoku płomienia sadzy powstającego w każdej strudze 
In the Figure 7 an image of the combustion chamber shows the sooting flames, the sensor position, the geometric angle between the coils and the swirl direction. The single sooting spray coils, who have their origin in the injector nozzle holes, can be seen very clearly. The sooting flames are detected as they pass the narrow observation area of the optical sensor. The emitted light intensity increases rapidly, as the soothing flame passes the detector.

Since the light intensity is proportional to the current, a peak in the measured signal trace can be observed. When more than one burning spray coil passes the detector, more peaks are detected. With the aid of the high resolution data acquisition system the time lap for two coils to pass the swirl sensor can be recorded, this is shown in Fig. 8.

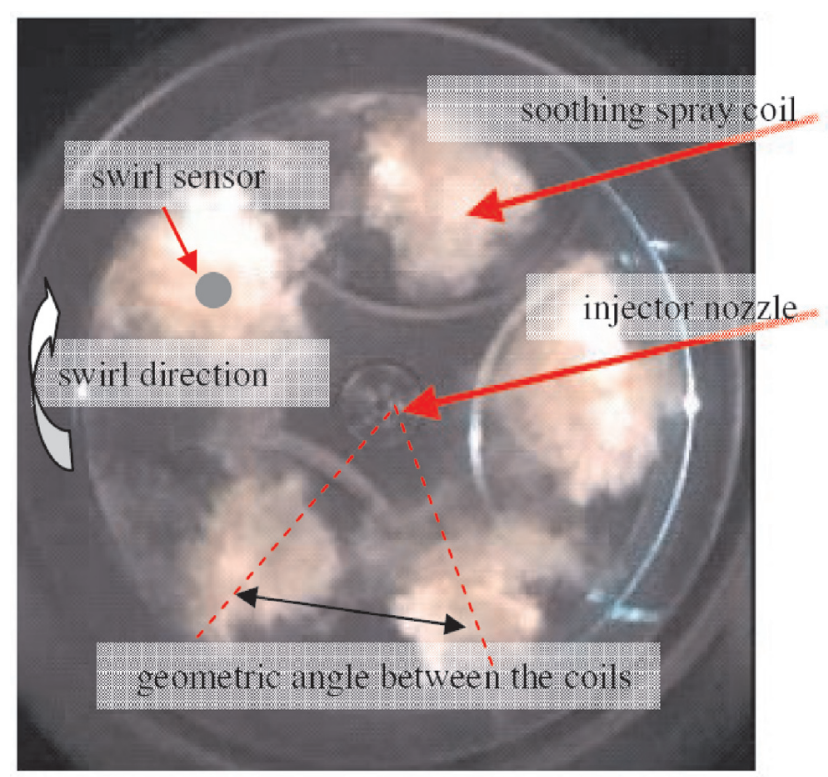

Fig. 7. Image of the combustion chamber showing the sooting flames, the sensor position, the geometric angle between the coils and the swirl direction

Rys. 7. Zdjęcie komory spalania pokazujące “chmury” płomienia sadzy, pozycję czujnika optycznego, ką geometryczny między wtryskiwanymi strugami paliwa i kierunek zawirowania

When the time period between two signal peaks is known, as well as the geometric angle between the spray coils, then the swirl ratio can be calculated by the equation:

$$
\begin{aligned}
& \mathrm{S}=\frac{\omega_{\mathrm{s}}}{\omega_{\mathrm{e}}}= \\
& =\frac{\text { geometric angle between the injector holes [deg] }}{\text { time period between two peaks [deg] }}
\end{aligned}
$$

The geometric angle between the coils is a production feature of the injector nozzle and can be determined from the construction drawings.

\section{Validation of the swirl sensor on an optical engine}

The optical probe system has been validated on an "optical engine", an engine with optical access to the combustion wtryskiwanego paliwa, który zaczyna obracać się w wyniku panującego zawirowania w cylindrze w obszarze detekcji czujnika. Przy bardzo silnym zawirowaniu obwodowym przebieg sygnału z pojedynczego cyklu wykazuje dużą wartość pierwszego maksimum podczas rozprzestrzeniania się płomienia oraz dwa lub trzy następne mniejsze maksima o niższym poziomie, powstające w wyniku przemieszczania się powstałych sąsiednich obłoków płomienia sadzy, które przemieszczają się w stożku detekcji czujnika.

Zdjęcie komory spalania na rys. 7 pokazuje "chmury" płomienia sadzy, pozycję czujnika optycznego, kąt geometryczny między wtryskiwanymi strugami paliwa oraz kierunek zawirowania. Pojedyncze obłoki płomienia sadzy, które mają swój początek na wylocie z otworka wtryskiwacza, mogą być łatwo zaobserwowane. Obłoki płomienia sadzy są wykrywane wówczas, kiedy zakryją wąski obszar detekcji pod czujnikiem optycznym. Emitowana intensywność światła wzrasta gwałtownie w chwili przemieszczania się obłoku płomienia pod czujnikiem.

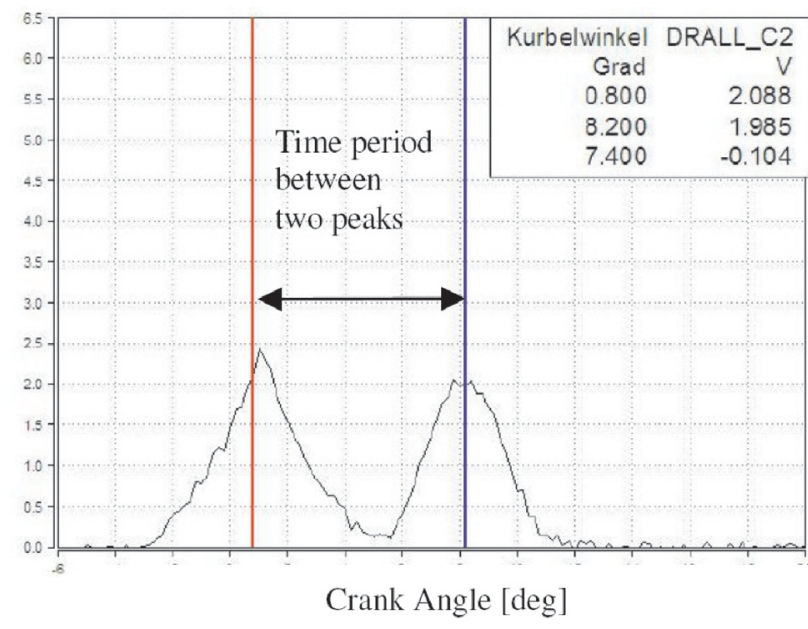

Fig. 8. The measured signal of the optical swirl sensor with the time period between the two signal peaks

Rys. 8. Sygnat pomiarowy z czujnika optycznego w okresie pomiędzy dwoma pikami sygnatu

Ponieważ intensywność promieniowania światła jest proporcjonalna do prądu elektrycznego, możliwa jest obserwacja piku rejestrowanego sygnału. Gdy więcej niż jeden palący się rdzeń strugi paliwa przesuwa się pod czujnikiem, rejestruje się więcej skoków wartości sygnału. W połączeniu z dużą rozdzielczością czasową rejestracji może być zarejestrowany czas przejścia dwóch strug płonącego paliwa, jak to pokazano na rys. 8 .

Gdy jest znany czas między dwoma impulsami sygnału oraz znany jest kąt geometryczny między strugami wtryskiwanego paliwa, możliwe jest określenie stopnia zawirowanie obwodowego zgodnie ze wzorem:

$$
\mathrm{S}=\frac{\omega_{\mathrm{S}}}{\omega_{\mathrm{E}}}=
$$

kat geometryczny miedzy otworami wtryskowymi [deg] 
chamber via a quartz glass window in the bottom of the piston bowl and by a mirror inserted into the piston from the side. The principal design of the optical DI-diesel engine was outlined in more detail in a previous paper by Hentschel [6]; the validation procedure should be described here just briefly. For a deeper view on the validation results refer to Hentschel et al. [7] or Czajka et al. [8].

Different optical techniques have been used to analyse the development of the in-cylinder swirl flow. Firstly, a particle image velocimetry (PIV) system was applied to the research engine and the swirl flow development during intake and compression stroke was measured. The engine was motored and the measurements were performed in a plane parallel to the cylinder head and about $10 \mathrm{~mm}$ below it. Measurements close to TDC were not possible later than $30 \mathrm{deg}$ CA before TDC because at that time, due to compression, the temperature inside the combustion chamber was so high that all types of oil seeding evaporate. The field of view is located above the piston crown and contains both the piston bowl and part of the squish area. PIV was used to analyse the in-cylinder intake flow and the development of the swirl on a cycle-averaged basis [10]. As shown in Fig. 9 a well defined swirl flow field is developed at $90 \mathrm{deg}$ CA before TDC. It looks very similar to a solid body rotation.

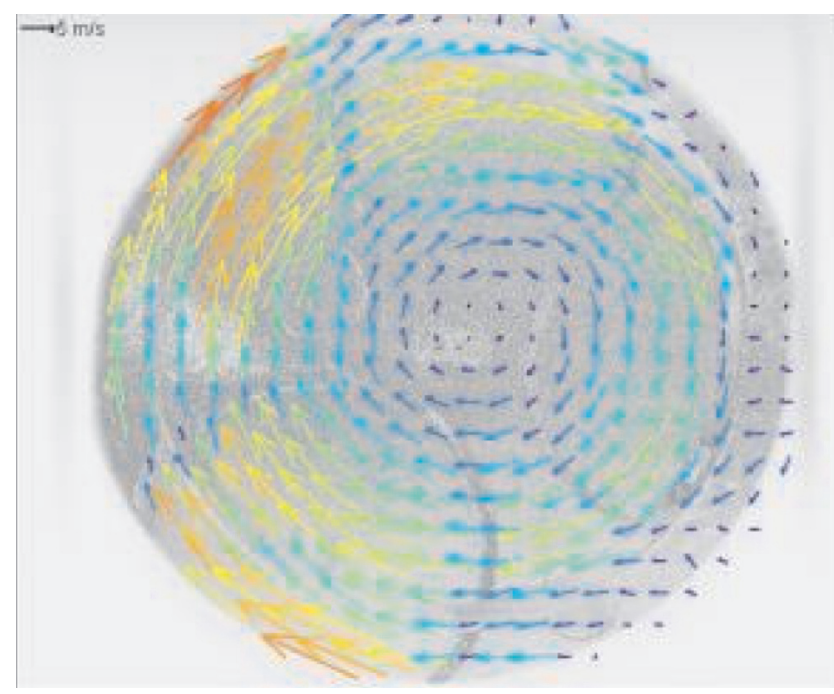

Fig. 9. Fully developed swirl flow during compression stroke Rys. 9. Calkowicie uksztaltowany wir obwodowy podczas suwu dolotu

Secondly, a high-speed video (HSV) technique with a framing rate of one frame per deg CA of the engine is applied to record both the flame propagation and the movement of soot clouds in the swirl flow inside and above the bowl-shaped combustion chamber. The setup for HSV is sketched in Fig. 10. A modern colour HSV CMOS camera with a high spatial and temporal resolution was used to get one frame per deg CA at the required engine speeds. A typical sequence of HSV frames taken in a single engine cycle is shown in Fig. 11. Every second frame of the video sequence has been skipped in the presentation. The influence of the in-cylinder swirl on the movement of the soot clouds can be clearly seen.
Geometryczny kąt między strugami wtryskiwanego paliwa jest parametrem konstrukcyjnym rozpylacza i jest określany z rysunków konstrukcyjnych.

\section{Kalibracja czujnika optycznego na silniku transparentnym}

System optycznego czujnika poddano kalibracji na silniku transparentnym, silniku z dostępem optycznym do komory spalania przez okno kwarcowe umieszczone w koronie tłoka i przez lustro wstawione do środka przedłużonego tłoka. Przykładowa konstrukcja silnika transparentnego o ZS z wtryskiem bezpośrednim została bardziej szczegółowo przedstawiona przez Hentschela [6]; procedura kalibracyjna tutaj będzie opisana skrótowo. Dokładniejszy wgląd w wyniki kalibracji można uzyskać w pracach Hentschela i in. [7] lub Czajki i in. [8].

Do analizy zawirowania obwodowego powstającego w cylindrze były wykorzystywane różne techniki optyczne. Przede wszystkim wykorzystano system PIV (Particle Image Velocimetry) w silniku badawczym do oceny powstawania zawirowania obwodowego podczas suwów dolotu i sprężania. Silnik był napędzany z zewnętrznego źródła energii, a pomiary przeprowadzono w płaszczyźnie równoległej do głowicy, ok. $10 \mathrm{~mm}$ poniżej niej.

Pomiary w pobliżu GMP nie były możliwe wcześniej niż $30^{\circ}$ OWK przed GMP, ponieważ w tym czasie - w wyniku sprężania - temperatura wewnątrz komory spalania była tak wysoka, że powodowała odparowanie kropel oleju tworzącego posiew. Pole obserwacji było zlokalizowane powyżej korony tłoka i obejmowało komorę spalania w tłoku oraz część przestrzeni wyciskającej tłoka. Metoda PIV była wykorzystana do analizy uśrednionego w ramach jednego cyklu przepływu do cylindra w czasie jego napełniania $\mathrm{i}$ powstawania zawirowania obwodowego [10]. Jak pokazano na rys. 9, wyraźnie określone zawirowanie obwodowe powstaje dla kąta $90^{\circ} \mathrm{OWK}$ przed GMP i wygląda podobnie do wirowania ciała stałego.

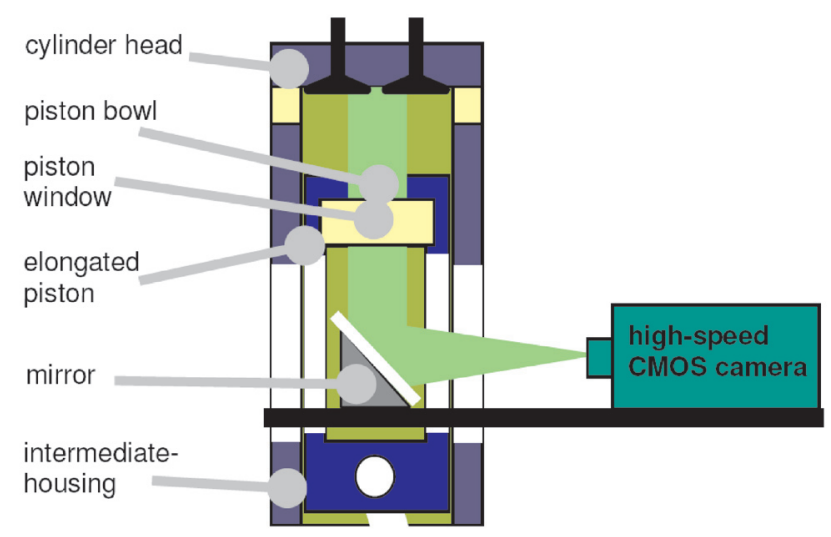

Fig. 10. Setup for high-speed video measurements on the DI diesel engine

Rys. 10. Schemat układu do badań na silniku o ZS z wtryskiem bezpośrednim

Następnie zastosowano technikę szybkiego filmowania HSV (high-speed video) z prędkością 1 klatki na 1 deg OWK 
For a clearer separation of the flame clouds, a 5-hole injector was used for this visualisation. Succeeding frames are evaluated two-by-two by a full-field correlation in a polar-coordinate system to achieve the characteristic number of the swirl strength and its development during a single combustion cycle. Evaluation of the images is meaningful after auto-ignition and first flame development have finished and the resulting soot clouds move in the swirling flow field. At the end of combustion, about $40 \mathrm{deg}$ CA after TDC, the soot is oxidised or cooled down and is no longer visible. The accuracy of this procedure is high enough to resolve even the light decrease in swirl strength during the engine cycle after TDC. do nagrania zdjęć rozprzestrzeniania się płomienia i przemieszczania się chmur sadzy w wirującym polu wewnątrz i nad półkulistą komorą spalania. Schemat systemu HSV przedstawiono na rys. 10. Wykorzystano do tego nowoczesną kolorową kamerę HSV z przetwornikiem CMOS, zapewniającą dużą rozdzielczość przestrzenną i czasową w celu uzyskania jednego zdjęcia na jeden stopień obrotu wału korbowego przy wymaganej prędkości obrotowej silnika. Typową sekwencję zdjęć wykonanych kamerą HSV dla pojedynczego cyklu spalania pokazano na rys. 11 . $\mathrm{W}$ przedstawionej sekwencji wykorzystano co drugie rejestrowane zdjęcie. Można zaobserwować wpływ zawirowania w cylindrze na ruch obłoków płomienia sadzy.

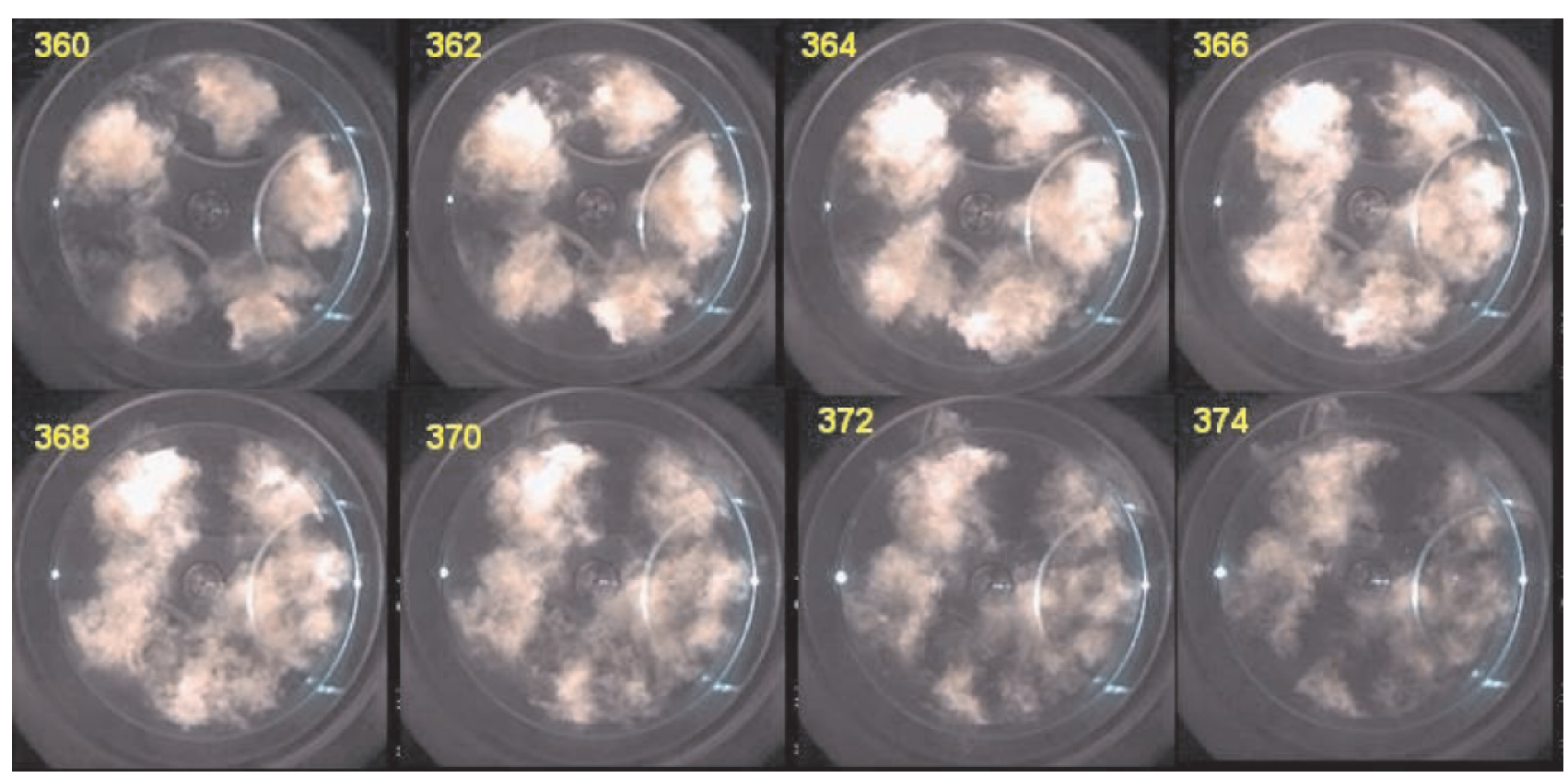

Fig. 11. HSV frames of swirling soot clouds in the engine cylinder, 5-hole injector; numbers indicate CA; $360 \mathrm{CA}=\mathrm{TDC}$ Rys. 11. Zdjęcia typu HSV wirujących chmur palacej się sadzy w cylindrze silnika, 5-otworkowy wtryskiwacz; liczby określają kąt OWK; 360 oznacza GMP

In the Figure 12 the three swirl results from the different optical measuring techniques, i.e. PIV, HSV and optical probe, are summarised. The simulated swirl ratio for every crank angle position is also included in the Fig. 12.

The real swirl in the cylinder differs from the solid body-type swirl assumed for the HSV correlation evaluations. The position of the optical probe is defined by the glow plug bore. At this location, the tangential flow component is slightly lower compared to the cylinder-averaged flow velocity. The positive results on the optical engine confirmed the functionality of the optical swirl sensor.

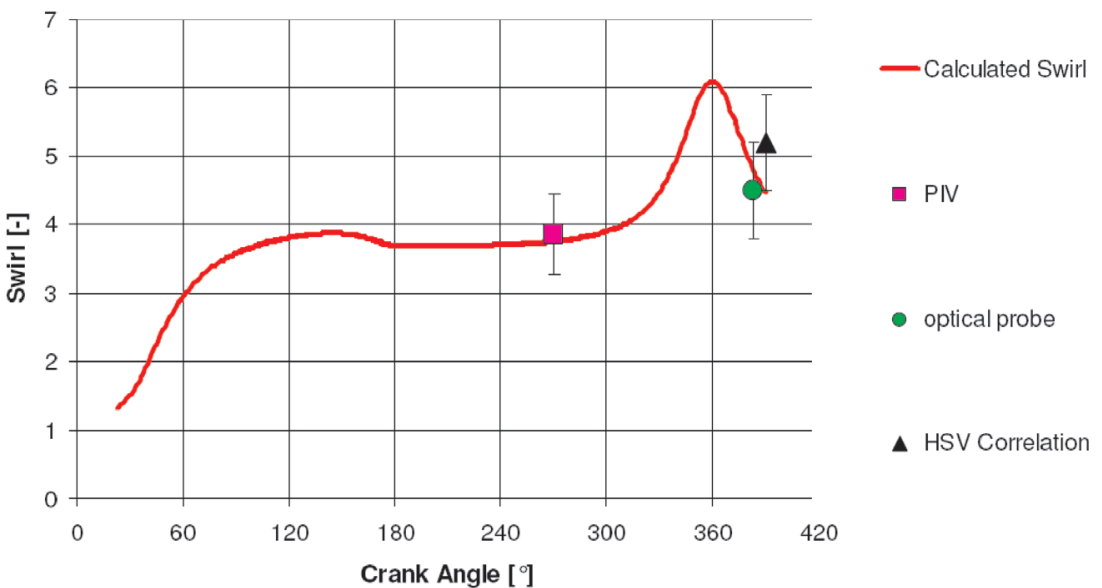

Fig. 12. Swirl flow development in an optical engine at $1200 \mathrm{rpm}$ - numerical simulation and data achieved by different experimental techniques

Rys. 12. Zmiany zawirowania obwodowego w silniku optycznym przy prędkości obrotowej $1200 \mathrm{obr} / \mathrm{min}$ - symulacja numeryczna (calculated swirl) $i$ wyniki uzyskana za pomoca różnych technik badawczych (PIV, czujnik optyczny, korelacja zdjęć HSV) 


\section{Experimental results}

\subsection{Test object}

After a thorough validation of the optical swirl sensor on the optical engine, the sensor was applied on a full serial turbocharged DI-diesel engine. The engine used for the swirl investigation is based on a Volkswagen $2.01 \mathrm{TDI}^{\circledR}$ engine. The bore and stroke of the engine are $81 \mathrm{~mm} \times 95.5 \mathrm{~mm}$. The injection system is a common rail system with rail pressures up to $1600 \mathrm{bar}$, and the nozzle used is equipped with 8 injection holes. The engine was equipped with a variable swirl valve in the spiral intake port [11].

When the swirl valve is opened, both ports (the spiraland tangential port) are flown through. This leads to a high flow charge coefficient and a low swirl number. By closing the variable swirl valve, the intake charge is forced to flow through the tangential intake port, causing a higher swirl number. Since only one intake port is being operated, the charge coefficient is reduced in this case. The behaviour of the cylinder head was measured on the Tippelmann test rig [2]; the results are shown in Fig. 13 and 14.

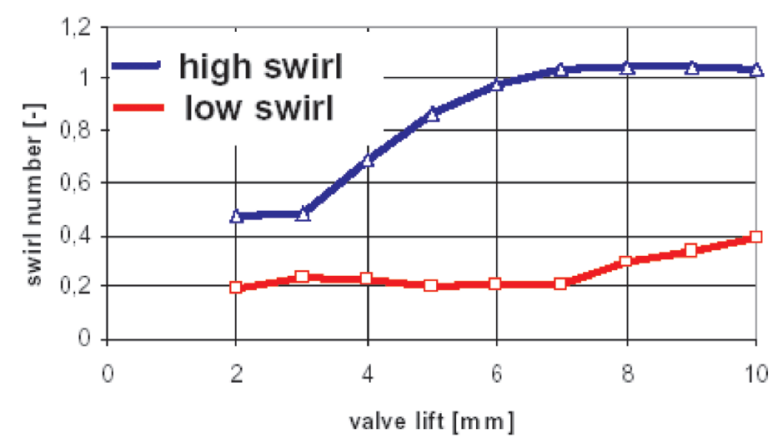

Fig. 13. Swirl number of the cylinder head from the steady-state Tippelmann test rig; blue line: high swirl case, red line: low swirl case

Rys. 13. Liczba wirowa określona na stanowisku badawczym Tippelmana; linia niebieska: przypadek dużego zawirowania, linia czerwona: przypadek małego zawirowania

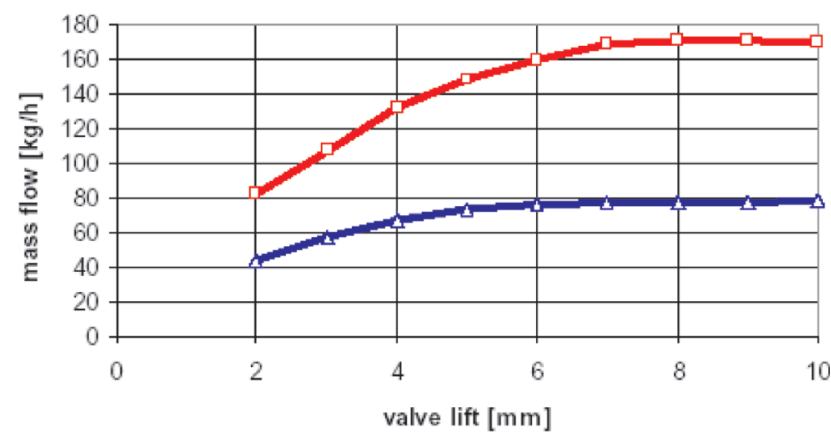

Fig. 14. Mass flow of the cylinder head from the steady-state Tippelmann test rig; blue line: high swirl case, red line: low swirl case

Rys. 14. Masowe natężenie przepływu określone na stanowisku badawczym Tippelmana; linia niebieska: przypadek dużego zawirowania, linia czerwona: przypadek matego zawirowania

Figure 13 shows the swirl number of the cylinder head from the steady-state Tippelmann test rig for the high swirl-
W celu lepszego rozdzielenia obłoków palącej się sadzy do tej wizualizacji wykorzystano wtryskiwacz 5-otworkowy. Kolejne zdjęcia oceniano, porównując je między sobą przy zastosowaniu autokorelacji we współrzędnych biegunowych dla określenia charakterystycznej liczby wirowej i zmian jej wartości podczas pojedynczego cyklu spalania. Ocena zdjęć staje się możliwa po wystąpieniu samozapłonu i po ukształtowaniu się pierwszego płomienia, a wynikające $\mathrm{z}$ niego chmury sadzy przemieszczają się w wirującym ośrodku. W końcowej fazie spalania, około $40^{\circ} \mathrm{OWK}$ po GMP, następuje utlenienie sadzy lub jej oziębienie i przestaje być widzialna. Dokładność opisanej procedury jest wystarczająco duża, mimo zmniejszenia się promieniowania w wirującym ośrodku w czasie trwania cyklu spalania po GMP.

Na rysunku 12 zestawiono trzy rodzaje wyników pomiarów zawirowania obwodowego otrzymane z wykorzystaniem różnych technik optycznych: PIV, HSV i optycznego czujnika. Ujęto na nim także symulację zawirowania dla każdej pozycji obrotu wału korbowego.

Rzeczywiste zawirowanie obwodowe panujące w cylindrze różni się od wirowania ciała stałego założonego w obliczeniach korelacyjnych zdjęć typu HSV. Pozycja czujnika optycznego wynika z położenia konstrukcyjnego otworu świecy żarowej. Takie położenie powoduje nieznaczne zmniejszenie składowej stycznej przepływu w porównaniu do średniej prędkości przepływu w całym cylindrze. Jednak pozytywne wyniki badań uzyskane na silniku transparentnym potwierdzają funkcjonalność czujnika zawirowania.

\section{Wyniki badań}

\subsection{Obiekt badań}

Po szczegółowych badaniach optycznego czujnika zawirowania przeprowadzonych na silniku transparentnym, czujnik zamontowano w silniku seryjnym turbodoładowanym z wtryskiem bezpośrednim o ZS. Silnik zastosowany w badaniach zawirowania opierał się na konstrukcji firmy Volkswagen $2.01 \mathrm{TDI}^{\circledR}$. Średnica cylindra i skok tłoka wynoszą odpowiednio $81 \mathrm{~mm} \times 95,5 \mathrm{~mm}$. Systemem wtryskowym był układ common rail o maksymalnym ciśnieniu w akumulatorze 1600 bar, w którym zastosowano rozpylacz 8-otworkowy. Silnik był wyposażony w zawór w kanale spiralnym pozwalający na uzyskanie zróżnicowanego zawirowania obwodowego [11].

Gdy zawór w kanale spiralnym jest otwarty, powietrze przepływa przez kanał spiralny i styczny. To powoduje uzyskanie dużego współczynnika napełniania i małej liczby wirowej. W czasie zamykania zaworu w kanale spiralnym cały ładunek przepływa przez kanał styczny, wywołując uzyskanie dużej liczby wirowej. Wykorzystanie tylko jednego kanału dolotowego wywołuje zmniejszenie współczynnika napełniania. Badania wpływu wykorzystania kanałów dolotowych do napełniania cylindra przeprowadzono z wykorzystaniem stanowiska Tippelmanna [2], uzyskane wyniki pokazano na rys. 13 i 14.

Rysunek 13 przedstawia wartości liczby wirowej uzyskane z badań głowicy na stanowisku Tippelmana dla przypadków dużego i małego zawirowania. Rysunek 14 
and the low swirl case. The Figure 14 shows the measured mass flow of the cylinder head for the high- and the low swirl case.

\subsection{Influence of the piston bowl geometry}

The design of the piston bowl has also an influence on the swirl ratio in the TDC. It is generally accepted that a smaller piston bowl diameter increases the swirl ratio at the TDC. This knowledge can be gained from 0D- and 3D simulation.

The optical swirl measurement technique allows measuring the influence of different piston bowl geometries on the swirl ratio in a real operating engine. Therefore, three piston variants were operated in the turbocharged DI-diesel engine. The sensor was mounted in the glow plug bore, without any mechanical changes of the cylinder head. The technical drawings of the pistons are shown in the Fig. 15, 16 and 17.

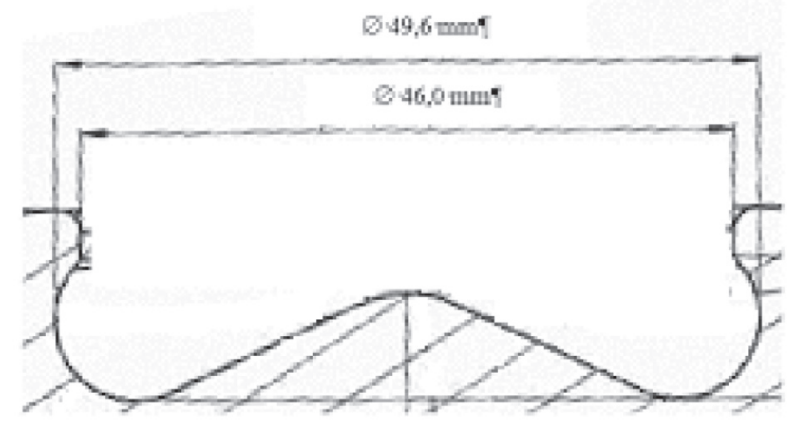

Fig. 15. Piston bowl geometry A, with a piston bowl diameter of 49,6 mm and a piston bowl neck diameter of $46 \mathrm{~mm}$

Rys. 15. Geometria komory spalania A, z średnica komory spalania 49,6 mm i z przewężeniem o średnicy $46 \mathrm{~mm}$

The three piston bowls were investigated on the same engine at $1500 \mathrm{rpm}$ and 6.2 bar mean effective pressure, without EGR and a start of injection of $12^{\circ}$ before the TDC. The swirl valve position was varied for the three pistons from completely closed to completely opened.

The rotation air impulse is being compressed from the cylinder diameter to the piston bowl diameter. It can be proven from the equation (6) that the moment of inertia of the charge about the cylinder axis for a bowl-in-piston combustion chamber can be written as [12].

$$
J_{i}=\frac{m_{c y l} d_{z}^{2}}{8} \cdot\left[\frac{\left(x_{i} / h\right)+\left(d_{M} / d_{z}\right)^{4}}{\left(x_{i} / h\right)+\left(d_{M} / d_{z}\right)^{2}}\right]
$$

The air mass in the cylinder has an influence on the moment of inertia and is being taken in account by the contribution mcyl. At the TDC the distance to the cylinder head is zero. The equation (10) can therefore be reduced to:

$$
\mathrm{J}_{\mathrm{TDC}, \mathrm{x}=0}=\frac{\mathrm{m}_{\mathrm{cyl}} \mathrm{d}_{\mathrm{z}}^{2}}{8}
$$

According to this equation the swirl ratio in the TDC will drop about $24 \%$ with the $53 \mathrm{~mm}$ (piston bowl B) in przedstawia wartości masowego natężenia przepływu w tych samych warunkach.

\subsection{Wpływ komory spalania umieszczonej w tloku}

Konstrukcja komory spalania umieszczonej w tłoku ma także wpływ na stopień zawirowania w okolicach GMP. Ogólnie przyjmuje się, że mniejsza średnica komory spalania w tłoku powoduje zwiększenie stopnia zawirowania. Taką wiedzę można otrzymać na podstawie symulacji w modelu 0- i 3D-wymiarowym.

Optyczna technika pomiaru zawirowania obwodowego pozwala na pomiar wpływu różnej geometrii komory spalania na stopień zawirowania występujący w silniku rzeczywistym. Dlatego w turbodoładowanym silniku o ZS z wtryskiem bezpośrednim przebadano trzy warianty tłoków. Czujnik zamontowano w gnieździe świecy żarowej bez jakichkolwiek zmian mechanicznych w głowicy. Rysunki konstrukcyjne tłoków przedstawiono na rys. 15, 16 i 17.

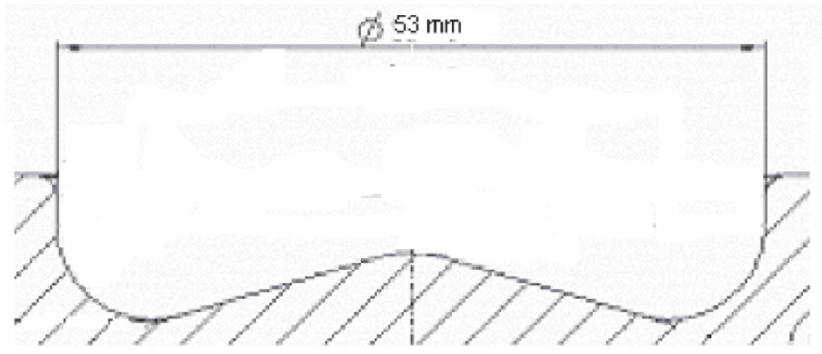

Fig. 16. Piston bowl geometry B, with a piston bowl diameter of $53 \mathrm{~mm}$ Rys. 16. Geometria komory spalania B, ze średnica komory spalania $53 \mathrm{~mm}$

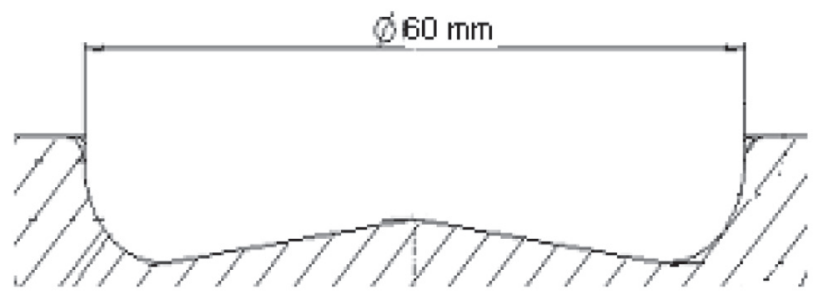

Fig. 17. Piston bowl geometry $\mathrm{C}$, with a piston bowl diameter of $60 \mathrm{~mm}$ Rys. 17. Geometria komory spalania C, ze średnica komory spalania $60 \mathrm{~mm}$

Te trzy komory spalania przebadano w tym samym silniku przy prędkości obrotowej 1500 obr/min i przy ciśnieniu użytecznym 6,2 bara, bez recyrkulacji spalin, a początek wtrysku występował $12^{\circ}$ przed GMP. Zawór zawirowujący w kanale spiralnym był ustawiony w trzech pozycjach: od całkowicie zamkniętego do całkowicie otwartego.

Impuls powodujący wirowanie powietrza zależy od stosunku średnicy cylindra do średnicy komory spalania. $\mathrm{Na}$ podstawie równania (6) można wykazać, że moment bezwładności wiru dookoła osi cylindra dla półkulistej komory w tłoku można napisać jako (10) [12].

Masa powietrza znajdująca się w cylindrze ma wpływ na moment bezwładności i jest uwzględniana w obliczeniach przez udział $m_{\text {cyl }}$. W GMP tłoka odległość od powierzchni głowicy wynosi zero. Dlatego równanie można zredukować do postaci (11). 
comparison to the piston with a bowl diameter of $49.6 \mathrm{~mm}$ and a neck diameter of $46 \mathrm{~mm}$ (piston bowl A). The swirl ratio of the variant 3 , with piston bowl diameter of $60 \mathrm{~mm}$, will decrease about $42 \%$.

The problem with the equation (10) is that the actual piston bowl geometry as designed in Fig. 15 cannot be taken in account, because only one value is considered for the piston bowl - and piston bowl neck diameter. The measurement results of the three piston variants are shown in the Fig. 18.

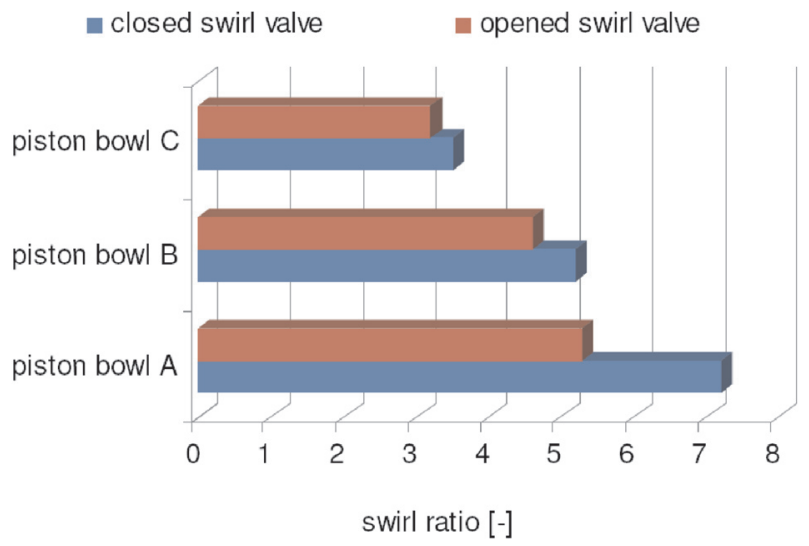

Fig. 18. Measured swirl ratios for three different pistons with an opened and a closed swirl valve constellation

Rys. 18. Zmierzone wartości liczby wirowej dla 3 różnych tłoków z otwartym (stupek czerwony) lub zamkniętym zaworem zawirowujacym (stupek niebieski)

The measurements shown in the Fig. 18, confirm the predicted decrease of the high swirl ratio when the piston bowl diameter is enlarged. By increasing the piston bowl diameter from 49.6 to $53 \mathrm{~mm}$, the swirl ratio is reduced from 7.2 to 5.2. This is a decrease of about $28 \%$, predicted was a swirl reduction of $24 \%$. Considering the measurement tolerances and the plain 0-Dimensional model, this is a good approximation. The swirl ratio is reduced from 7.2 to 3.5 between the piston bowl geometries $\mathrm{A}$ and $\mathrm{C}$, this represents a reduction in swirl ratio of about $51 \%$. The equation 11 derived a prediction of $42 \%$. The same measurements were made for the low swirl case with an opened swirl valve. As expected the swirl ratios in the Fig. 18 are lower than those of the closed valve measurements. Also the drop of swirl ratio between the variants is smaller than in the case above.

Between the piston bowl geometries A and B the swirl ratio is reduced by $13 \%$ and between the geometries $\mathrm{A}$ and $\mathrm{C}$ by $31 \%$. It can be observed, that in the low swirl case the measured drop in swirl ratio is lower than the predicted values. In the high swirl case the decay of swirl ratio is higher than calculated by equation 10 . This could be explained by the simplification of the 0D-models, where the dissipation effects are neglected. Another factor which can lead to inaccurate results are the boundary conditions of the input data in the 0Dmodel. The Tippelmann test rig delivers mass flow and swirl number under steady state conditions. The 0D-model uses this information together with the valve lift timing to calculate the in-cylinder-mass and the rotation impulse. All
Zgodnie z tym równaniem stopień zawirowania, gdy tłok jest w GMP, obniży się o około $24 \%$ w przypadku, gdy komora spalania miała średnicę $53 \mathrm{~mm}$ (komora spalania B) w porównaniu do tłoka, w którym średnica komory spalania wynosi 49,6 mm z przewężeniem o średnicy 46 mm (komora spalania A). Stopień zawirowania w trzecim przypadku, gdy średnica komory spalania wynosi $60 \mathrm{~mm}$, zmniejsza się o ok. $42 \%$.

W przypadku komory spalania w tłoku z przewężeniem, przedstawionej na rys. 15 , powstaje problem $\mathrm{z}$ wykorzystaniem równania (10), ponieważ w równaniu tym można uwzględnić tylko jedną wartość średnicy. Dlatego komora ta została rozpatrzona dla średnicy komory spalania i dla średnicy przewężenia. Wyniki uzyskane z pomiarów przy zastosowaniu trzech różnych komór spalania przedstawiono na rys. 18 .

Wyniki badań przedstawione na rys. 18 potwierdzają przewidywane zmniejszenie stopnia zawirowania, gdy średnica komory spalania w tłoku jest zwiększona. Przy powiększeniu średnicy komory z 49,6 mm do $53 \mathrm{~mm}$, następuje zmniejszenie stopnia zawirowania z 7,2 do 5,2. Jest to zmniejszenie średnicy o około $28 \%$, które powoduje zmniejszenie stopnia zawirowania o 24\%. Zważywszy na błąd pomiaru i wyniki otrzymane z modelu 0-wymiarowego jest to dobre przybliżenie. Zmniejszenie stopnia zawirowania z 7,2 do 3,5 w przypadku zastosowania odpowiednio komory spalania A i C stanowi redukcję stopnia zawirowania o około $51 \%$. Zgodnie z równaniem (11) zmniejszenie stopnia zawirowania wynosi $42 \%$. Takie same badania przeprowadzono dla przypadku małego zawirowania przy otwartym zaworze w kanale spiralnym. Jak oczekiwano, wartości stopnia zawirowania na rys. 18 są mniejsze niż w sytuacji, gdy zawór w kanale spiralnym był zamknięty. Także zmniejszenie stopnia zawirowania pomiędzy wariantami tłoka jest mniejsze niż w omówionym wyżej przypadku.

Pomiędzy komorą spalania A i B zmniejszenie stopnia zawirowania wynosi 13\%, a między komorą A i C - 31\%. Można zauważyć, że w przypadku małego zawirowania zmniejszenie liczby wirowej uzyskane na podstawie pomiarów jest mniejsze niż określone na podstawie obliczeń. W przypadku dużego zawirowania spadek stopnia zawirowania jest większy niż obliczony na podstawie równania (11). Można to wytłumaczyć uproszczeniem modelu 0-wymiarowego, gdzie efekt dyssypacji został pominięty. Innym czynnikiem, który może prowadzić do niedokładności wyników są warunki brzegowe w danych wejściowych do modelu 0-wymiarowego. Badania na stanowisku Tippelmanna dostarczają dane do modelu o masowym natężeniu przepływu oraz o liczbie wirowej. Te dane są wykorzystywane w modelu 0-wymiarowym razem z danymi o wzniosie zaworu do obliczania masy powietrza dopływającej do cylindra i impulsu obrotowego powietrza. Wszystkie warunki niestacjonarnego przepływu gazu rozumiane jako fala ciśnienia w układzie dolotowym, rzeczywiste ciśnienie doładowania, turbulencje w układzie dolotowym itp. zostały pominięte.

\section{Podsumowanie}

Emisja związków toksycznych oraz zużycie paliwa w silnikach o ZS z wtryskiem bezpośrednim są regulowane 
the instationary gas flow effects as pressure waves in the intake system, the real boost pressure, turbulent intake flow effects, etc. are neglected.

\section{Conclusion}

The exhaust gas emissions and the fuel consumption in DI-diesel engines is governed by the interaction of the swirling flow with the high pressure fuel injection. An improved understanding of the swirling flow field during the combustion process can lead to a better compromise between the exhaust gas emissions (i.e. soot, $\mathrm{NO}_{\mathrm{x}}, \mathrm{HC}$ and $\mathrm{CO}$ ) and the fuel consumption.

It is generally accepted that the piston bowl geometry and the swirl valve position influence the swirl ratio of a DIdiesel engine. The effect of these variations can be modelled with a $0 \mathrm{D}$ or $3 \mathrm{D}$ model. In these models numerous assumptions, for example the estimation of the turbulence factor, the friction coefficient, have to be made. The validation of such empirical factors is made on special steady state test rigs or on optical engines.

The goal of this work is to develop a measuring technique to determine the swirl ratio in a full serial DI-diesel engine. The result is an optical swirl sensor which can be easily mounted on a series production engine by just replacing the glow plug. In the validation experiments the formation of the swirl flow in the cylinder during the compression stroke and the swirl strength during the combustion process have been analysed by means of different optical methods: PIV, a HSV correlation method, and the optical probe technique. The methods complement each other.

PIV measurements have been performed during the intake and compression stroke, but not later than $30^{\circ} \mathrm{CA}$ before TDC. The application of the HSV correlation method and the optical probe technique are restricted to the combustion phase when bright soot clouds are present. For PIV and HSV correlation an optical engine with large scale optical access to the combustion chamber is required. The validation results have shown that the optical probe is well suited to measure the in-cylinder swirl during combustion.

In this work the influence of the swirl valve position and the piston bowl geometry in a full DI diesel engine on the swirl strength is examined. For the piston bowl variation there was a good correlation between the 0D model and the optical swirl results.

The 0D model was not fully able to reproduce the measurements of the low swirl case. The optical swirl measurement system allows detecting the inaccuries in the 0D model and gaining deep insights in the tangential flow field during the combustion phase.

The system can be used to study the influence of hardware parts and engine applications on the swirling flow in a DI-diesel engine. These results allow achieving an optimised configuration in relation to the raw exhaust gas emissions and fuel consumption. The swirl sensor has been found to be a powerful tool to optimise the swirl strength in the development process for future low emission DI diesel engines. przez wzajemne oddziaływanie przepływu wirowego i wysokociśnieniowego wtrysku paliwa. Lepsze wyjaśnienie przebiegu zawirowania obwodowego w czasie przebiegu procesu spalania może prowadzić do uzyskania lepszego kompromisu między emisją związków toksycznych (tj. PM, $\mathrm{NO}_{x}, \mathrm{HC}$ i CO) a zużyciem paliwa.

Ogólnie przyjmuje się, że geometria komory spalania i położenie zaworu w kanale spiralnym wpływają na stopień zawirowania w silniku o ZS z wtryskiem bezpośrednim. Skutki wprowadzania tych zmian konstrukcyjnych można zamodelować z wykorzystaniem modelu 0-wymiarowego lub 3D-wymiarowego. W tych modelach konieczne jest przyjęcie wielu założeń, np. szacunkowego stopnia turbulencji, współczynnika tarcia. Określenie wartości takich współczynników doświadczalnych następuje na podstawie badań stacjonarnych na stanowiskach badawczych lub w silnikach z dostępem optycznym.

Celem tego artykułu jest przedstawienie techniki pomiarowej do określania liczby wirowej w całkowicie seryjnym silniku o ZS z wtryskiem bezpośrednim. Dzięki tej technice powstał czujnik optyczny zawirowania, który w łatwy sposób można zamontować na silniku seryjnym, wykręcając jedynie świecę żarową. Podczas badań eksperymentalnych powstawanie zawirowania w cylindrze w czasie suwu sprężania oraz w czasie procesu spalania analizowano z wykorzystaniem różnych metod optycznych: PIV, HSV i czujnika optycznego. Metody te wzajemnie się uzupełniały.

Badania z wykorzystaniem systemu PIV były prowadzone w czasie suwów dolotu i sprężania, jednak tylko do $30^{\circ}$ OWK przed GMP. Badania z wykorzystaniem szybkiego filmowania HSV oraz czujnika optycznego są ograniczone do czasu spalania, kiedy są widoczne obłoki płomienia sadzy. Do badań korelacyjnych metod PIV i HSV oraz czujnika optycznego konieczne było zapewnienie dużego dostępu optycznego do komory spalania. Otrzymane wyniki potwierdzają, że optyczny czujnik zawirowania jest odpowiednim narzędziem pomiarowym do określania stopnia zawirowania w czasie procesu spalania.

W pracy przeanalizowano również wpływ ustawienia zaworu w kanale spiralnym i geometrii komory spalania na siłę zawirowania w seryjnym silniku o ZS z wtryskiem bezpośrednim. Dla różnych komór spalania wystąpiła dobra korelacja wyników między modelem 0-wymiarowym a optycznym czujnikiem zawirowania.

Model 0-wymiarowy nie umożliwił odwzorowania wyników uzyskanych w przypadku małego zawirowania. Optyczny system pomiarowy zawirowania pozwolił na wykrycie niedokładności modelu 0-wymiarowego i pozwolił na dokładniejsze zapoznanie się z obwodowym polem przepływów w czasie spalania.

System może być używany do określania wpływu zmian konstrukcyjnych w silniku i jego zastosowania na zawirowanie obwodowe w silniku Diesla z bezpośrednim wtryskiem paliwa. Rezultaty badań pozwoliły osiągnąć optymalną konfigurację dla zmniejszenia emisji powstających związków toksycznych i zmniejszenie zużycia paliwa. Czujnik zawirowania został uznany za pełnowartościowe narzędzie 


\section{Acknowledgements}

The Authors would like to thank Dr.-Ing. Dieter Karst of the Fa. Kistler Instruments for his contribution and efforts to adapt and optimise the measurement technique for optical swirl measurements. We would also like to thank Dipl.-Ing. Bernd Hahne, Dr.-Ing. Emanuela Montefrancesco, Dr.-Ing. Gerhard Ohmstede, Dipl.-Ing. Stefan Schmerbeck, Dipl.-Ing. Gerald Block of the Volkswagen R\&D and Prof. Krzysztof Wisłocki of the TU-Poznan for their support and the numerous discussions about the internal combustion process.

Artykut recenzowany do optymalizacji siły zawirowania dla projektowanych $\mathrm{w}$ przyszłości niskoemisyjnych silników o ZS z wtryskiem bezpośrednim.

\section{Podziękowanie}

Autorzy dziękują Panu dr. inż. Dieterowi Karstowi z firmy Kistler Instruments za wkład i wysiłek, jaki włożył w zaadaptowanie i optymalizację techniki pomiarowej dla optycznego czujnika pomiaru zawirowania. Dziękują również mgr. inż. Berndtowi Hahne, dr. inż. Emanueli Montefrancesco, dr. inż. Gerhardowi Ohmstede, mgr. inż. Stefanowi Schmerbeckowi, mgr. inż. Geraldowi Blockowi z działu badawczo-rozwojowego firmy oraz prof. Krzysztofowi Wisłockiemu z Politechniki Poznańskiej za wsparcie i liczne rozmowy na temat procesu spalania.

\section{Nomenclature/Oznaczenia}

\section{CA Crank Angle/kat OWK}

DI Direct Injection/wtrysk bezpośredni

EGR Exhaust Gas Recircualtion/recyrkulacja spalin

HSV High Speed Video/szybkie filmowanie

IVO Inlet Valve Opening/otwarcie zaworu dolotowego

IVC Inlet Valve Closing/zamknięcie zaworu dolotowego

$\mathrm{m} \quad$ mass flow rate $[\mathrm{kg} / \mathrm{s}] /$ masowe natężenie przeplywu $[\mathrm{kg} / \mathrm{s}]$

$\mathrm{m}_{\mathrm{cyl}} \quad$ air mass in the cylinder $[\mathrm{kg}] /$ masa powietrza w cylindrze $[\mathrm{kg}]$

$\mathrm{M}$ total torque $[\mathrm{N} \cdot \mathrm{m}] /$ calkowity moment obrotowy $[\mathrm{N} \cdot \mathrm{m}]$
$\mathrm{M}_{\mathrm{r}} \quad$ friction moment $[\mathrm{N} \cdot \mathrm{m}] /$ moment tarcia $[N \cdot \mathrm{m}]$
PIV Particle Image Velocimetry/metoda określania prędkości przemieszczania czastek
$\mathrm{V}$ volumetric flow rate $\left[\mathrm{m}^{3} / \mathrm{s}\right] /$ objętościowe natężenie prze- pływu $\left[\mathrm{m}^{3} / \mathrm{s}\right]$
TDC Top Dead Center/górne martwe położenie tłoka
$\alpha \quad$ cam shaft angle/kat obrotu watu korbowego
$\rho \quad$ density in the cylinder $\left[\mathrm{kg} / \mathrm{m}^{3}\right] / g$ estossć $w$ cylindrze $\left[\mathrm{kg} / \mathrm{m}^{3}\right]$
$\omega \quad$ air angular velocity $[1 / \mathrm{s}]$ /prędkość katowa powietrza [1/s]

\section{Bibliography/Literatura}

[1] Tippelmann G.: A new method of investigation for swirl ports. SAE Technical Paper Series 770404, 1977.

[2] Abgasgesetzgebung der Europäischen Union PKW und leichte Nutzfahrzeuge (70/220/EWG).

[3] Heywood J.B.: Internal combustion engine fundamentals. McGraw-Hill Book Co, 1988.

[4] Kunte S., Boulouchos K., Hentschel W., Kallmeyer F., Cavalloni C., Karst D.: Optical indicating on combustion engines with smallest sensors. Proc. 10. Symp The Working Process of the Internal Combustion Engine, Graz 2005.

[5] Wolter T.: Optische Dralluntersuchung an einem TDI®. Diploma Thesis, R\&D Volkswagen AG, 2006, in German, not published.

[6] Hentschel W.: Modern tools for diesel engine combustion investigation, 26. Symp. (Int.) on Combustion/The Combustion Institute, Naples, pp. 2503-2515, 1996.

[7] Hentschel W., Ohmstede G., Block G., Vanhaelst R., Schmerbeck S., Czajka J., Wisłocki K., Karst D.: Multiple swirl flow

Prof. Robin Vanhaelst, DEng. - professor at the University of Applied Sciences Braunschweig/Wolfenbuettel, Wolfsburg, Germany.

Dr inż. Robin Vanhaelst - profesor w Wyższej Szkole Technicznej Braunschweig/Wolfenbuettel, Wolfsburg, Niemcy.

e-mail: robinvanhaelst@aol.com

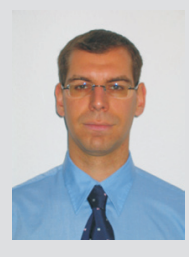

Mr. Werner Hentschel, DSc. - employee at Research and Development - Metrology Department in Volkswagen AG, Wolfsburg, Germany.

Dr Werner Hentschel - pracownik Dzialu BadawczoRozwojowego firmy Volkswagen, Wolfsburg, Niemcy. e-mail:werner.hentschel@volkswagen.de analysis in a direct-injection diesel engine. Proc. 12. Int. Symp. on Flow Visualization, 10-14. Sept. 2006, Göttingen.

[8] Czajka J.: Zur Bestimmung des Dralls in Diesel Brennverfahren. Diploma thesis, VW Wolfsburg/TU-Poznan 2005, in German, not published.

[9] Steiger W., Kohnen C.: New combustion systems based on a new fuel specification. Proc 26. Int. Vienna Engine Symp, pp. 91-110, Vienna 2006, in German.

[10] LaVision. DaVis-Software, version 7, PIV-Module.

[11] Rudolph F., Hadler J., Engler H.-J., Röpke S.: Der neue 2,01 4V TDI ${ }^{\circledR}$ mit Common-Rail - Moderne Dieseltechnologie von Volkswagen The New $2.014 \mathrm{~V}$ TDI ${ }^{\circledR}$ with Common Rail - Stateof-the-Art Diesel Technology from Volkswagen, Volkswagen AG, Wolfsburg 2007.

[12] Pischinger R., Kell M., Sams T.: Thermodynamik der Verbrennungskraftmaschine - Der Fahrzeugantrieb. Springer Wien-New York 2002, in German. Proc Instn Mech Engrs Vol 208, Part D: Journal of Automobile Engineering 1994.

Mr. Christian Müller, Dipl.-Ing.-- engineer in the Volkswagen AG, Research and Development, Wolfsburg, Germany.

Inż. Christian Müller - inżynier w Dziale BadawczoRozwojowym firmy Volkswagen AG, Wolfsburg, Niemcy.

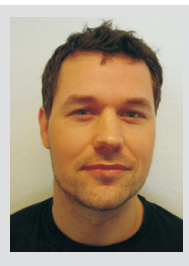

Mr. Jakub Czajka, MEng. - doctorate in the Institute of Combustion Engines and Transportation at the Poznan University of Technology, Poland.

Mgr inż. Jakub Czajka - doktorant w Instytucie Silników Spalinowych i Transportu Politechniki Poznańskiej, Polska.

e-mail:jakubczajka@o2.pl 